\title{
ФІЛОСОФІЯ
}

\section{UDC $392.544: 176$ \\ POSTMODERN WORLD AND MORALS: SOME THOUGHTS ON SEX, POLYANDRY, AND POLYGYNY}

DANYLOVA T.V., PhD in Philosophy, Associate Professor of the Department of Philosophy

National University of Life and Environmental Sciences of Ukraine, ORCID ID 0000-0002-0297-9473

E-mail: danilova tv@ukr.net

YUDINA V.Y., Faculty of Linguistics and Social Communications

National Aviation University

ORCID: 0000-0001-9985-6068

E-mail: caulfield1249@gmail.com

\begin{abstract}
Postmodern worldview requires a change of focus on the place and role of the traditional social institutions and habitual behaviors within them. The attitude towards sex has changed massively over the last decades. Practices that were once considered wrong and absurd (such as premarital sex and same-sex conducts) are now considered by most people as normal and acceptable. However, what is the reason for changing attitudes towards intimate relationships and is it really a new experience for our society or have various types of marriages actually appeared a long time ago? The paper aims to investigate such phenomena as "polyandry" and "polygyny" and explore whether there is the only one right moral way of relationships or it still depends on cultural features. During the research, the authors have used the comparative-historical method, the methodology of philosophical hermeneutics, as well as the integrative anthropological approach.
\end{abstract}

Keywords: sex, polyandry, polygyny, morality, cultural phenomenon.

Introduction. Postmodern worldview requires a change of focus on the place and role of the traditional social institutions and habitual behaviors within them. The latest researches state that significant differences in attitudes towards sex were found among different generations. The greatest gap was between the generations of the Second World War born between the 1920s and 1940s and their children born during the Baby Boom period (the 1940s - 1960s). However, there was still a noticeable difference between millennials (born in the early 1980s) and their parents. In the 1950s men and women usually did not live to- gether until marriage; unmarried women who gave birth to children were destitute; and homosexuality was considered shameful. Today, we have completely different attitudes towards sex.

Analysis of recent researches and publications. The influence of the family on premarital sexual attitudes and behavior were studied by A. Thornton and D. Camburn [20]. B. Christlieb explored sexual attitudes through the lens of family sexual communication and demographic factors [3]. M. Müberra and N. Çeliközb have analyzed positive/negative impacts of different parental attitudes on children's sexual identity and character develop- 
ment [13]. C.L. Somers and C. Anagurthi revealed the association between parental consistency/inconsistency of values toward adolescents' premarital sexual activity and adolescents' own premarital sex attitudes and behaviors [15]. A comprehensive analysis of polygyny, polyandry and polyamory was carried out by $D$. Young, S. Young and K. Young [22]. Different forms of marriage around the world were analyzed by J. Peoples and G. Bailey in their book "Humanity: An Introduction to Cultural Anthropology" [14].

Purpose. The paper aims to investigate such phenomena as "polyandry" and "polygyny" and explore whether there is the only one right moral way of relationships or it depends on cultural features. During the research, the authors have used the comparative-historical method, the methodology of philosophical hermeneutics, as well as the integrative anthropological approach.

Results. According to recent studies conducted in the United States, it has been found that the general recognition of premarital sex has doubled in the last 40 years. In the 1970 s, only $29 \%$ of Americans said that premarital adult sex was "not that bad idea". In the 80s and 90s of the last century, this percentage jumped to a mark of $42 \%$. In the 2000 s, $49 \%$ supported the idea of premarital sex, and in 2019 it grew to $61 \%$. In addition, the adoption of same-sex relationships has tripled over the past 26 years changing the mark from $13 \%$ (1993) to $44 \%$ (2019). Legislation of same-sex marriages reflects these changes in relation to sex [11].

J. M. Twenge, R.A. Sherman and B.E. Wells suggest that changes are likely to be related to the growth of "cultural individualism" in the United States. They note that in songs' lyrics and writing singular pronouns such as "l" and "You" are more often used rather than plural form "We" [21]. Researches show that the attitude towards sexuality is fixed at the beginning of life: it is influenced by such factors as the relationship between parents, sexual upbringing of a child, a society in which this child grows and develops, and other children he communicates with. Sex-related changes are very important as it may affect the following attitudes: sexually transmitted diseases, pregnancy (accidental pregnancy), attitude towards domestic violence and person's mental health.

In order to understand why changes in attitude towards sex have been caused, it is necessary to identify whether individual mood has changed over time or simply replaced by new generations who think differently. Researchers have determined that changes are due to the effect of a cohort (the discovery of similar features in the way of thinking and behavior of a certain group of individuals who were born in the same historical and cultural environment). Such an effect occurs when younger and older generations have different attitudes to one subject. The younger generation is more likely to perceive same-sex relationships and premarital sex than the old one, but the attitude towards such relationships has become more liberal in all age groups, especially between 1990's and 2000's.

This brings us to the fundamental evolutionary question: is human adapted to a particular form of social organization and a certain system of sexual relationships by his biological nature? Comparing different cultures, it becomes obvious that people as species are exceptionally changeable in both respects. Comparison of a human with other primates also does not give a definite answer, but despite the ambiguity of the situation, many authors try to solve this problem very simply: they consider chimpanzees as a "frozen ancestor" and conclude that initially our ancestors were characterized by multi-group and promiscuity. Others hit the opposite extreme emphasizing that the available data is not enough for investigation and therefore it is impossible to make an unequivocal conclusion about the social structure and system of sexual relations of our ancestors. Moreover, it is widely 
believed that social organization and the system of sexual relations in humans do not have biological bases at all and are entirely determined by social norms adopted in human society. According to this view, monogamous marriage is a purely social construct, not associated with any biological predisposition. But, according to R. Martin, those and other extreme views do not stand up to scrutiny [12].

J. Henrich, R. Boyd and P.J. Richerson emphasized that "monogamous marriage reduces crime" drawing the results of a study showing that societies, where polygyny is spread, have a large number of unmarried men, the presence of which correlates with an increased level of rape, theft, murder, and abuse of psychotropic substances: "By expanding the pool of unmarried men and elevating the degree of intra-sexual competition, more polygynous marriages will increase men's discounting of the future and risk-taking, resulting in more socially undesirable behaviors. Faced with high levels of intra-sexual competition and little chance of obtaining even one long-term mate, unmarried, low-status men will heavily discount the future and more readily engage in risky status-elevating and sex-seeking behaviors. This will result in higher rates of murder, theft, rape, social disruption, kidnapping (especially of females), sexual slavery and prostitution. As a by-product, these men will probably engage in more substance abuse. Even among high-status males, competition can intensify if the fitness gradient remains steep. This can lead to risky bids for political power motivated by the possibility of acquiring harems. By contrast, normative monogamy drains the pool of low-status unmarried men resulting in lower rates of social ills, including reduced rates of crime, social disruption and substance abuse" [10, p. 660-661].

It seems to be logical and no more arguments could change this point of view, but if we describe all possible forms of family life, we can see that each socie- ty has its own specific form of family organization. Another social institution, the institution of marriage, is closely associated with the institution of the family. Marriage is a socially sanctioned, socially and personally appropriate, sustainable form of sexual relations. In the legal sense, marriage is a legally defined voluntary and free union of partners aimed at creating a family and generating mutual personal as well as property rights and obligations of the spouses. In the world there are many forms of marriage including polyandry and polygyny.

Polyandry is a woman's relationship with several men. Not so long ago the presence of polyandry was recognized only in some nations of Tibet, but today, as anthropologists have confirmed, this type of marriage occurs in 53 nations. According to K.E. Starkweather and R. Hames's survey, anthropologists have documented social systems for polyandric unions in a variety of environments ranging from the Arctic to the tropics and the desert. Recognizing that at least half of these groups are hunting societies, the authors of the survey came to the conclusion that the polyandry has a profound human history and should be examined from an evolutionary perspective [17]. The roots of polyandry go to matriarchy the formation of a family around the power of a woman. There is no unambiguous theory about whether society passed through the idea of matriarchy. Some supporters argue that it was (at the stage when gathering and farming were practiced, but not hunting). Others argue that it was not at all [4; 9].

There is another view on the existence of polyandry - the theory of adaptation. According to this theory, polyandry is needed in some places for survival and safety. And for adaptation all means are good. For example, in places with scarce resources, this will slow the growth of population and infant mortality. It also solves the problem of inheritance, if the brothers from the same family marry the same woman. "In other cultures, it ap- 
pears that a man may arrange a second husband (again, frequently his brother) for his wife because he knows that, when he must be absent, the second husband will protect his wife-and thus his interests. And if she gets impregnated while Husband \#1 is gone, it will be by someone of whom he has approved in advance. Anthropologists have recorded this kind of situation among certain cultures among the Inuit (the people formerly called Eskimos)" [8].

Polyandry is more often found in remote corners of the Earth (villages, tribes). For example, it is the norm of the Bari tribe. Moreover, they believe that several male seeds can be given to the child at once. And not only "polyandry" is practiced, but also "multi parenthood". According to the results of Beckerkman's investigations, the children in Bari realize that the chances of surviving up to 15 years are significantly higher if there are two fathers [1]. For them, this is to be expected, but for us it is often a real rejection, which once again confirms the influence of culture and the history of society on the human psyche. "The Bari are an excellent example of a group that practices informal polyandry and believes in partible paternity... the Bari believe that successive sperm deposits "build" a baby inside of a woman. Therefore, every man that a woman takes as a lover during her pregnancy is thought to contribute to the biological makeup of the baby and, therefore, is considered to be a biological father of the baby. After the child is born, any men that the mother recognizes as fathers of the baby are responsible for providing continual gifts of meat and other valuable resources to the child and will also step in and take over the duties of the primary father if he dies" [16, p. 9-10].

Polygyny is a form of marriage where a man makes an alliance with several women. Polygyny is recognized in Islam, where according to the Quran, a Muslim is allowed to have up to four legal wives. The social roots of polygyny do not lie in the erotic preferences of men, but in social and economic factors. In societies of early pastoralists and farmers, wives are legally acquired as the labor force. In addition, by entering into marriage, the householder expands and strengthens his social ties with other clans, therefore the prestige of his clan raises. Social prestige, measured by the number of social connections, is the main "capital" in all pre-industrial societies.

The concept itself is divided into:

- $\quad$ sororal - wives are sisters;

- non-sororal - the wives of one man do not have any ties of kinship.

Polygyny is quite common in Muslim countries where polygamy is allowed. The status of a man is determined by the number of wives he has. The man is obliged to maintain his wives as well as be liable for common children. Sororal polyginous families are much stable than non-sororal ones as there is a big rivalry between wives.

The historian S. Coontz, who studied the institute of marriage in various cultures, pointed out that "polygyny is less about sex than it is about power. Rich old guys with lots of wives win twice: They have more women to bear them babies and do household work, and they also gain an advantage over other men. After all, in such societies a young man in want of a wife cannot simply woo her. There is too much competition, and he probably has too little to offer. So he winds up having to do work for a more powerful, polygynous man, bringing him gifts and tributes, in hopes of someday being rewarded with one of that man's many daughters" [5].

The family is recognized by all researchers as the main carrier of cultural patterns inherited from generation to generation, as well as a necessary condition for the socialization of the individual. Namely, in a family a person gets acquainted with social roles, receives basic education and behavioral skills. The rules, principles, customs and traditions of family life are specific to each society. At the same time, each society is con- 
vinced that only its certain schemes for family life, family customs and foundations are the best and only possible, which means that family life is perceived through the lens of ethnocentrism. Ethnocentrism is a view of society in which a certain group is considered central, and all other groups are commensurate and correlate with it [19].

The family as a social institution has several functions: lation;

- the function of sexual regu-

- $\quad$ the reproductive function;

- $\quad$ the function of socialization;

- the economic function.

- the function of emotional satisfaction;

- $\quad$ the status function;

- $\quad$ the protective function;

All these functions can be updated and satisfied within the framework of both polyandry and polygyny. Therefore, polyandry and polygyny should be viewed from the perspective of cultural relativism, which is based on the statement that members of one social group cannot understand the motives and values of the other groups if they analyze these motives and values through the lens of their own culture $[6 ; 7 ; 18]$. In order to understand another culture, it is necessary to associate its specific features with the situation and peculiarities of its development. Each cultural element should be related to the characteristics of the investigated culture. The value and significance of any element can only be considered in the context of a particular culture.

Conclusions. In her interview, S. Coontz stressed that "every society has variations on what a family is. Men and women have different definitions within the same household. There has always been diversity within each society and changes within that notion" [2]. In conclusion we can say that there is no one pattern for morality, as morality could be different in each culture. The morality is due to social, economic, cultural, geographic and many other features. Regarding to social evolution, the best form of marriage and family for a particular society is not what is "moral", but what works and can be safe in all meanings.

\section{References}

1. Beckerman, S., Lizarralde, R., Lizarralde, M., Bai, J., Ballew, C., Schroeder, S., Dajani, D., Walkup, L., Hsiung, M., Rawlins, N., Palermo, M. (2002). The Bari Partible Paternity Project, Phase One. In Cultures of Multiple Fathers: The Theory and Practice of Partible Paternity in Lowland South America. Stephen Beckerman and Paul Valentine, eds. Gainesville, FL: University Press of Florida, 228.

2. Benjamin, R. (2006). Interview of Stephanie Coontz. Mediate.com. - Retrieved from https://www.mediate.com/articles/benjami ncoontz.cfm

3. Christlieb, B. (2016). The Development of Sexual Attitudes in the Family of Origin and Sexual Satisfaction Later in Life. University of Nevada. - Retrieved from https://digitalscholarship.unlv.edu/cgi/view con-

$\underline{\text { tent.cgi?article }=3655 \& \text { context }=\text { thesesdiss }}$ ertations

4. Cichon, J.M. (2013). Matriarchy in Minoan Crete: A perspective from archaemythology and modern matriarchal studies (Dissertatin, PhD). San Francisco, CA: California Institute of Integral Studies, 554.

5. Copeland, L. (2012). Is Polygamy Really So Awful? SLATE - Retrieved from https://slate.com/humaninterest/2012/01/the-problem-withpolygamy.html

6. Danylova, T.V. (2012). Problema liudskoi identychnosti u postmodernii kartyni svitu [The Problem of Human Identity In Postmodern Worldview]. Anthropological Measurements of Philosophical Research, 2, 1622. 
7. Danylova, T.V. (2017). Searching for the True Self: The Way of Nondual Wisdom. Anthropological Measurements of Philosophical Research, 12, 7-15. Doi 10.15802/ampr.v0i12.119069.

8. Dreger, A. (2013). When taking Multiple Husbands Make Sense. The Atlantic - Retrieved from https://www.theatlantic.com/health/archiv e/2013/02/when-taking-multiplehusbands-makes-sense/272726/

9. Eller, C. (2001). The Myth of Matriarchal Prehistory: Why an Invented Past Won't Give Women a Future. Beacon Press, 276.

10. Henrich, J., Boyd, R., Richerson, P.J. (2012). The puzzle of monogamous marriage. Philosophical Transactions of the Royal Society B; Biological Sciences, 367(1589), 657-669. doi: $10.1098 /$ rstb.2011.0290

11. Making up our minds: attitudes towards sex are changing. (2015). The Conversation - Retrieved from https://theconversation.com/making-upour-minds-attitudes-towards-sex-arechanging-42994

12. Martin, R. (2013). How We Do It: The Evolution and Future of Human Reproduction. Basic Books, 320.

13. Müberra, M., Çeliközb, N. (2009). Impacts of parental attitude towards sexual identity development on child's sexual identity development. Procedia Social and Behavioral Sciences, 1, 1408-1413.

14. Peoples, J., Bailey, G. (2017). Humanity: An Introduction to Cultural Anthropology. Cengage Learning; 11 edition, 480.
15. Somers, C.L., Anagurthi, C. (2013). Parents' attitudes about adolescents' premarital sexual activity: The role of inter-parent consistency/inconsistency in sexual outcomes. Health Education Journal, 73(5), 545-553. https://doi.org/10.1177/001789691350670 2.

16. Starkweather, K.E. (2010). Exploration into Human Polyandry: An Evolutionary Examination of the NonClassical Cases. University of Nebraska. - Retrieved from http://digitalcommons.unl.edu/cgi/viewcon tent.cgi ?article $=1005 \&$ context $=$ anthrothes es

17. Starkweather, K.E, Hames, R. (2012). A Survey of Non-Classical Polyandry. Human Nature, 23(2), 149 - 172.

18. Storozhuk, S.V., Hoyan, I.M. (2017). Gender Equality as a Modern Phenomenon. Anthropological Measurements of Philosophical Research, 11, 71-83. DOI: 10.15802/ampr.v0i11.105481

19. Sumner, W. G. (2007). Folkways: A Study of Mores, Maneers, Customs and Morals. Cosimo Classics, 704.

20. Thornton, A., Camburn, D. (1987). The influence of the family on premarital sexual attitudes and behavior. Demography, 24(3), 323-340.

21. Twenge, J.M., Sherman, R.A., Wells, B.E. (2015). Changes in American Adults' Sexual Behavior and Attitudes, 1972 - 2012. Archives of Sexual Behavior, 44(8), 2273-2285.

$$
\text { 22. Young, D., Young, S., }
$$
Young, K. (2013). Polygamy: Polygyny, Polyandry, and Polyamory. Fifth Estate, 220.

\section{ПОСТМОДЕРНИЙ СВІТ І МОРАЛЬ: ДЕКІЛЬКА ДУМОК ПРО СЕКС, ПОЛІАНДРІЮ І ПОЛІГІНІЮ \\ Данилова Т.В., Юдіна В.Я.}

Анотація. Світогляд доби постмодерну потребує нового погляду на місце $і$ роль традиційних соціальних інститутів і усталених моделей поведінки. Ставлення до сексу суттєво змінилося за останні десятиліття. Практики, які колись сприймались як неправильні й навіть абсурдні (наприклад, дошлюбний і одностатевий секс), зараз більшість людей вважають нормальними й прийнятними. Однак 
що же причиною такої зміни, яка відбулась у ставленні до інтимних відносин, чи $\epsilon$ це дійсно новим досвідом для нашого суспільства, чи різні типи шлюбів виникли давно? Метою статmі є дослідження таких френоменів як «поліандрія» $і$ «полігінія», а також з'ясування того, чи існує єдиний правильний моральний спосіб взаємовідносин, чи залежить він від культурних особливостей. У процесі дослідження було застосовано порівняльно-історичний метод, методологію фрілософрської герменевтики, а також антропологічний інтегративний підхід.

Ключові слова: секс, поліандрія, полігінія, мораль, культурний феномен. 